\title{
PREDICTION OF VAPOR-LIQUID EQUILIBRIA WITH CHEMICAL REACTION BY ANALYTICAL SOLUTIONS OF GROUPS
}

\author{
Katsumi TOCHIGI, Shigeki MINAMI and Kazuo KOJIMA \\ Department of Industrial Chemistry, Nihon University, Tokyo 101
}

\begin{abstract}
To discuss prediction of vapor-liquid equilibria with esterification on the basis of the ASOG model, infinite-dilution binary activity coefficients were measured for five systems in the $40^{\circ}$ $100^{\circ} \mathrm{C}$ range by an ebulliometric method. The systems measured are methyl acetate- $n$-heptane, ethyl acetate-ethanol, ethyl acetate-water, acetic acid- $n$-heptane, and acetic acid-ethyl acetate. The group Wilson parameters for any system made up of $\mathrm{CH}_{2}, \mathrm{OH}, \mathrm{COO}, \mathrm{COOH}$ groups were determined in the $40^{\circ}-100^{\circ} \mathrm{C}$ range by infinite-dilution activity coefficients. Vapor-liquid equilibria predicted for three quaternary esterification systems and for $\mathbf{2 6}$ binary and ternary systems involving alcohols, water, paraffins, esters, and carboxylic acids agreed fairly well with observed values.
\end{abstract}

\section{Introduction}

Extensive studies of experimental and theoretical aspects of vapor-liquid equilibria have been undertaken in the past, though mostly on systems in which no chemical reaction occurs. Apparently, few studies of vapor-liquid equilibria of systems in which chemical reaction occurs in liquid phase, such as esterification, have been made. Komatsu, Hirata et al. ${ }^{11-13)}$ observed vapor-liquid equilibria of quaternary systems, like acetic acid-alcohols-water-esters, with esterification and proposed an empirical method for correlating vapor-liquid equilibria with esterification by using vapor-liquid equilibrium ratio. $\mathrm{Nishi}^{21>}$ observed vapor-liquid equilibria for the acetic acid- $i$-propanolwater-i-propyl acetate system and showed that the data could be correlated satisfactory by the method of Komatsu, Hirata et al., Suzuki, Komatsu and Hirata ${ }^{35)}$ tried to correlate vapor-liquid equilibria with esterification on the basis of activity coefficient equations for the purpose of developing an empirical method.

An ASOG (Analytical Solutions of Groups) model constitutes a predictive method ${ }^{5,8,36)}$ for obtaining activity coefficients. It is a widely applicable method requiring minimum experimental data and is of practical use in predicting vapor-liquid and liquid-liquid equilibria. Derr and Deal ${ }^{5}$ suggested application of ASOG to reaction systems. Hardly any studies seems to have been reported, however, for concrete application of ASOG to reaction systems.

The present paper deals with prediction of vapor-

Received March 10,1977. Correspondence concerning this article should be addressed to K. Kojima. S. Minami is now with Tsukishima Kikai Co., Ltd., Tokyo 104. liquid equilibria with esterification by ASOG model. Here, the group Wilson parameters for any system made up of $\mathrm{CH}_{2}, \mathrm{OH}, \mathrm{COO}, \mathrm{COOH}$ groups were determined first in the $40^{\circ}-100^{\circ} \mathrm{C}$ range by the ebulliometric method. Next, by applying the group Wilson parameters, prediction of vapor-liquid and vaporliquid-liquid equilibria was made for 22 binary systems constituted by $\mathrm{CH}_{2}-\mathrm{COO}, \mathrm{CH}_{2}-\mathrm{OH}-\mathrm{COO}$, $\mathrm{CH}_{2}-\mathrm{OH}-\mathrm{COOH}, \mathrm{CH}_{2}-\mathrm{COO}-\mathrm{COOH}$ groups and four ternary systems constituted by $\mathrm{CH}_{2}-\mathrm{OH}-\mathrm{COO}$ groups. Further prediction of vapor-liquid equilibria with esterification has been made for the acetic acidethanol-water-ethyl acetate, acetic acid- $i$-propanolwater- $i$-propyl acetate and acetic acid- $n$-butanolwater-butyl acetate systems.

1. Measurement of Infinite Dilution Activity Coefficients

Group Wilson parameters necessary for predicting vapor-liquid equilibria with esterification by using ASOG are those relating to the six group pairs (made up of $\mathrm{CH}_{2}, \mathrm{OH}, \mathrm{COO}$ and $\mathrm{COOH}$ groups) $\mathrm{CH}_{2}-\mathrm{COO}$, $\mathrm{OH}-\mathrm{COO}, \mathrm{CH}_{2}-\mathrm{COOH}, \mathrm{OH}-\mathrm{COOH}, \mathrm{COO}-\mathrm{COOH}$, $\mathrm{CH}_{2}-\mathrm{OH}$. For the sake of simplicity, no distinction is made between $\mathrm{CH}_{3}$ and $\mathrm{CH}_{2}$ groups ${ }^{27,31}$.

Several attempts ${ }^{30,34,36)}$ have been made for experimentally determining group Wilson parameters. In the previous study ${ }^{36}$, the authors discussed the method for determining the parameters by infinite dilution activity coefficients measured by using ebulliometer and determined group Wilson parameters for any system made up of $\mathrm{CH}_{2}, \mathrm{OH}, \mathrm{CO}$ groups in the $40^{\circ}-100^{\circ} \mathrm{C}$ range. The infinite dilution activity co- 
Table 1 Observed binary activity coefficients at infinite dilution

\begin{tabular}{cccccc} 
System & $\gamma_{1}^{\infty}$ & 40 & 60 & 80 & 100 \\
\hline Methyl acetate (1) & $r_{1}^{\infty}$ & 3.63 & 3.80 & 3.99 & 4.19 \\
$n$-Heptane (2) & $r_{2}^{\infty}$ & 4.82 & 5.12 & 5.37 & 5.58 \\
Ethyl acetate (1) & $r_{1}^{\infty}$ & 2.77 & 2.53 & 2.25 & 1.94 \\
$\quad$ Ethanol (2) & $r_{2}^{\infty}$ & 3.29 & 2.82 & 2.44 & 2.14 \\
Ethyl acetate (1) & $r_{1}^{\infty}$ & - & - & - & - \\
Water (2) & $r_{2}^{\infty}$ & 11.88 & 10.40 & 9.23 & 8.32 \\
Acetic acid (1) & $r_{1}^{\infty}$ & 24.66 & 18.86 & 18.11 & 17.50 \\
$n$-Heptane (2) & $\gamma_{2}^{\infty}$ & 10.57 & 11.30 & 12.74 & 15.14 \\
Acetic acid (1) & $r_{1}^{\infty}$ & 1.22 & 1.40 & 1.57 & 1.75 \\
Ethyl acetate (2) & $r_{2}^{\infty}$ & 1.17 & 1.21 & 1.25 & 1.29 \\
\hline
\end{tabular}

efficients for a binary system consisting of acetic acid, a self-associating component, and water were measured $^{38)}$ in the $60^{\circ} \mathrm{C}-110^{\circ} \mathrm{C}$ range.

In the present study, infinite dilution activity coefficients have been measured for five binary systems made up of $\mathrm{CH}_{2}, \mathrm{OH}, \mathrm{COO}, \mathrm{COOH}$ groups by the ebulliometric method. The experimental apparatus used is the same as that in the previous paper ${ }^{38)}$. The systems measured are methyl acetate- $n$-heptane $\left(\mathrm{CH}_{2}-\right.$ $\mathrm{COO}$ system), ethyl acetate--ethanol, ethyl acetatewater $\left(\mathrm{CH}_{2}-\mathrm{OH}-\mathrm{COO}\right.$ systems), acetic acid- $n$-heptane $\left(\mathrm{CH}_{2}-\mathrm{COOH}\right.$ system $)$, acetic acid-ethyl acetate $\left(\mathrm{CH}_{2}-\right.$ $\mathrm{COO}-\mathrm{COOH}$ system). Bubble points were measured for about 15 compositions at 760,600, 400, 200, 150 $\mathrm{mm}$ of $\mathrm{Hg}$ and at intervals of about $2 \mathrm{~mol} \%$ in the dilute regions (less than $10 \mathrm{~mol} \%$, greater than $90 \mathrm{~mol} \%$ ). For a heterogeneous liquid system of ethyl acetate-water, the bubble points were measured in a region in which concentration of ethyl acetate is rich. The bubble points were not measured in the ethyl acetate-dilute region, because a two-liquid phase was formed in the region of less than about $3 \mathrm{~mole} \%$ ethyl acetate. Infinite dilution activity coefficients were obtained for water in ethyl acetate alone.

Reagents other than water used in the experiments were of special grade (Wako Pure Chem. Ind. Ltd.). Distilled water was used after ion exchange.

Measurement of infinite dilution binary activity coefficients from $T-x$ data for the three binary systems constituted by ethyl acetate (1)- $n$-heptane (2), ethyl acetate (1)-ethanol (2), ethyl acetate (1)-water (2) is based on calculations using Eqs. (1) and $(2)^{10,16)}$.

$$
\begin{aligned}
& \gamma_{1}^{\infty}=\left(P / P_{1}^{0}\right)\left\{1-\left(\partial T / \partial x_{1}\right)\left(d \ln P_{2}^{0} / d T\right)\right\}_{x_{1}=0} \\
& \gamma_{2}^{\infty}=\left(P / P_{2}^{0}\right)\left\{1-\left(\partial T / \partial x_{2}\right)\left(d \ln P_{1}^{0} / d T\right)\right\}_{x_{2}=0}
\end{aligned}
$$

Assuming that the formation of higher aggregates than dimer for acetic acid is negligible in the vapor phase, Eqs. (3) and (4) below, derived earlier ${ }^{38)}$, were applied for computing the infinite dilution activity coefficients for two binary systems containing acetic acid (which is a self-associating component): acetic acid (1)- $n$-heptane (2) and acetic acid (1)-ethyl acetate (2). Thus

$$
\begin{aligned}
\gamma_{1}^{\infty}= & \left(P / P_{1}^{0}\right)\left\{1-\left(\partial T / \partial x_{1}\right)\left(d \ln P_{2}^{0} / d T\right)\right\}_{x_{1}=0} \\
\gamma_{2}^{\infty}= & \left(P / P_{2}^{0}\right)\left[\left\{1-\left(\partial T / \partial x_{2}\right)\left(d \ln P_{1}^{0} / d T\right)\right\}\left(2-\eta_{1}\right)\right. \\
& \left.-\left(\partial T / \partial x_{2}\right)\left(d \ln K_{2} / d T\right)\left(1-\eta_{1}\right)\right]_{x_{2}=0}
\end{aligned}
$$

where $P_{1}^{0}$ and $P_{2}^{0}$ denote, respectively, the vapor pressures of acetic acid monomer ${ }^{38}$ ) and component 2 , and $K_{2}$ represents the vapor-phase association constant of dimerization for acetic acid, calculated on the basis of the data ${ }^{28}$ obtained from Ritter et al. As for $\eta_{1}$, it is the true mole fraction of acetic acid monomer in vapor phase and is calculated ${ }^{17,38)}$ by applying Eq. (5).

$$
\eta_{1}=\left(-1+\sqrt{ } 1+4 K_{2} P\right) / 2 K_{2} P
$$

Terminal slopes for the $T-x$ curve, $\left(\partial T / \partial x_{1}\right)_{x_{1}=0}$, $\left(\partial T / \partial x_{2}\right)_{x_{2}=0}$ were evaluated by the Ellis and Jonah $\operatorname{method}^{7}$. Vapor pressures for pure materials are calculated by applying the Antoine equation. Thus

$$
d \ln P_{i}^{0} / d T=2.303 B_{i} /\left(t^{\circ} \mathrm{C}+C_{i}\right)^{2}
$$

Table 1 shows the infinite dilution binary activity coefficients for components 1 and 2 in the $40^{\circ}-100^{\circ} \mathrm{C}$ range by applying Eqs. (1) and (2) for the methyl acetate- $n$-heptane, ethyl acetate-ethanol, ethyl acetatewater systems and by applying Eqs. (3) and (4) for the acetic acid- $n$-heptane, acetic acid-ethyl acetate systems.

\section{Determination of Group Wilson Parameters}

On the basis of the ASOG (Analytical Solutions of Groups) model ${ }^{5,30,36)}$, the activity coefficients are calculated with the help of Eqs. (7) to (9).

$$
\begin{aligned}
& \log \gamma_{i}= \log \gamma_{i}^{\mathrm{FH}}+\log \gamma_{i}^{\mathrm{G}} \\
& \log \gamma_{i}^{\mathrm{FH}}= \log \left\{\nu_{i}^{\mathrm{FH}} /\left(\sum_{j=1}^{n} x_{j} \nu_{j}^{\mathrm{FH}}\right)\right\} \\
&+0.434\left\{1-\nu_{i}^{\mathrm{FH}} /\left(\sum_{j=1}^{n} x_{j} \nu_{j}^{\mathrm{FH}}\right)\right\} \\
& \log \gamma_{i}^{(\mathrm{G}}= \sum_{k} \nu_{k i}\left(\log \Gamma_{k}-\log \Gamma_{k}^{(i)}\right) \\
& \log \Gamma_{k}=-\log \sum_{l} X_{l} a_{k / l} \\
&+0.434\left[1-\sum_{l}\left\{X_{l} a_{l / k} /\left(\sum_{m} X_{m} a_{l / m}\right)\right\}\right] \\
& X_{k}=\sum_{i=1}^{n} x_{i} \nu_{k i} i \sum_{i=1}^{n} x_{i} \sum_{\nu_{k i}}
\end{aligned}
$$

where $\nu_{i}^{\mathrm{FH}}$ represents the number of atoms (other than the hydrogen atoms) in the molecular species $i$, and $\nu_{k i}$ is the number of interaction groups of kind $k$ in molecule $i$. The entities $\Gamma_{k}$ and $X_{k}$ represent, respectively, the group activity coefficient and the group fraction of group $k$. As for $a_{k / l}, a_{l / k}$, these are group Wilson parameters. Activity coefficients are calculated by substituting known values of $a_{k / l}, a_{l / k}$ in Eqs. (7) to (9).

As for the method of determining the group Wilson 
Table 2 Constants $m_{k / l}$ and $n_{k / l}$ in Eq. (10) $\left(40^{\circ}-100^{\circ} \mathrm{C}\right)$

\begin{tabular}{|c|c|c|c|c|c|c|c|c|c|}
\hline \multirow[b]{2}{*}{$k$} & \multirow{2}{*}{$l$} & \multicolumn{2}{|c|}{$\mathrm{CH}_{2}$} & \multicolumn{2}{|c|}{$\mathrm{OH}$} & \multicolumn{2}{|c|}{$\mathrm{COO}$} & \multicolumn{2}{|c|}{$\mathrm{COOH}$} \\
\hline & & $m_{k / l}$ & $n_{k / l}$ & $m_{k / l}$ & $n_{k / l}$ & $m_{k / l}$ & $n_{k / l}$ & $m_{k / l}$ & $n_{k / l}$ \\
\hline $\mathrm{CH}_{2}$ & & 0 & 0 & -0.4962 & -11.2 & -0.1209 & 18.1 & -0.3307 & 150.6 \\
\hline $\mathrm{OH}$ & & 0.6007 & -767.1 & 0 & 0 & 0.1616 & -286.1 & 0.7907 & -418.6 \\
\hline $\mathrm{COO}$ & & -0.3730 & 41.5 & -0.0615 & 52.5 & 0 & 0 & 1.2470 & -363.1 \\
\hline $\mathrm{COOH}$ & & 0.1364 & -265.6 & -0.5256 & 223.3 & -2.2885 & 690.0 & 0 & 0 \\
\hline
\end{tabular}

parameters on the basis of infinite dilution activity coefficients, this consists of calculation of twelve group Wilson parameters made up of the six group pairs $\mathrm{CH}_{2}-\mathrm{COO}, \mathrm{OH}-\mathrm{COO}, \mathrm{CH}_{2}-\mathrm{COOH}, \mathrm{OH}-$ $\mathrm{COOH}, \mathrm{COO}-\mathrm{COOH}, \mathrm{CH}_{2}-\mathrm{OH}$ under the condition of constant temperature as follows: First the group Wilson parameters for $\mathrm{CH}_{2}-\mathrm{COO}$ system are determined on the basis of the infinite dilution activity coefficients of methyl acetate $n$-heptane. The number $\nu_{\text {CoO }}$ of COO groups in methyl acetate used in the calculation is 3 , i.e. $\nu_{\mathrm{COO}}=3$. This value is the same as that used by Derr and Deal ${ }^{5}$. The group Wilson parameters for $\mathrm{OH}-\mathrm{COO}$ system are calculated on the basis of the infinite dilution activity coefficients of ethyl acetate-ethanol and ethyl acetate-water by using known values of $a_{\mathrm{CH}_{2} / \mathrm{H}}, a_{\mathrm{OH} / \mathrm{CH}_{2}}$ obtained in the previous paper ${ }^{36)}$. The water molecule is treated ${ }^{36)}$ as 1.6 interaction hydroxyl groups. The group Wilson parameters for $\mathrm{CH}_{2}-\mathrm{COOH}$ system are calculated on the basis of the infinite dilution activity coefficients of acetic acid- $n$-heptane. The number $\nu_{\text {соо н }}$ of $\mathrm{COOH}$ groups in acetic acid used in the calculation is 3, i.e. $\nu_{\mathrm{COOH}}=3$. The group Wilson parameters for $\mathrm{COO}-$ $\mathrm{COOH}$ system are calculated on the basis of the infinite dilution activity coefficients of acetic acidethyl acetate by using known values of $a_{\mathrm{CH}_{2} / \mathrm{COOH}}$, $a_{\mathrm{COOH} / \mathrm{CH}_{2}}$. The group Wilson parameters for $\mathrm{OH}_{-}$ $\mathrm{COOH}$ system are calculated by using known values of $a_{\mathrm{CH}_{2} / \mathrm{OH}}, a_{\mathrm{OH} / \mathrm{CH}_{2}}, a_{\mathrm{CH}_{2} / \mathrm{COOH}}, a_{\mathrm{COOH}_{/ \mathrm{CH}_{2}}}$ on the basis of the infinite dilution activity coefficients of acetic acid-water given in the previous paper ${ }^{38}$.

Figure 1 shows group Wilson parameters (determined at $40^{\circ}, 60^{\circ}, 80^{\circ}$ and $100^{\circ} \mathrm{C}$ ) plotted against the temperature. As is evident from the figure, the logarithms of group Wilson parameters are inversely proportional to the absolute temperature in the temperature range in this work. Therefore

$$
\log a_{k / l}=m_{k / l}+n_{k / l} / T
$$

where $m_{k / l}$ and $n_{k / l}$ are constants with respect to group pairs. Table 2 shows the constants $m_{k / l}$ and $n_{l^{\prime} / l}$ for any system made up of $\mathrm{CH}_{2}, \mathrm{OH}, \mathrm{COO}$, $\mathrm{COOH}$ groups. In Table 2, the constants for the $\mathrm{CH}_{2}-\mathrm{OH}$ system obtained in the previous paper ${ }^{36}$ ) are also shown.

\section{Prediction of Vapor-Liquid Equilibria for Binary and Ternary Systems}

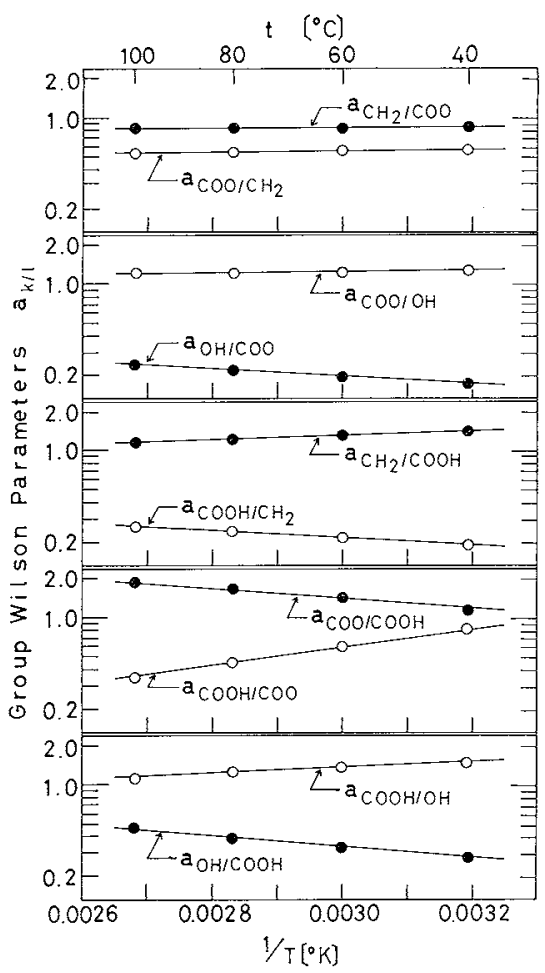

Fig. 1 Variation of group Wilson parameters with temperature

Prediction on vapor-liquid equilibria with esterification has been preceded by that on vapor-liquid equilibria using the group Wilson parameters for 22 isobaric binary systems (Table 3 ) constituted by $\mathrm{CH}_{2}-\mathrm{COO}$, $\mathrm{CH}_{2}-\mathrm{OH}-\mathrm{COO}, \mathrm{CH}_{2}-\mathrm{OH}-\mathrm{COOH}, \mathrm{CH}_{2}-\mathrm{COO}-\mathrm{COOH}$ groups and four isobaric ternary systems (Table 4) constituted by $\mathrm{CH}_{2}-\mathrm{OH}-\mathrm{COO}$ groups. The systems discussed include those with two liquid phases, namely ethyl acetate-water, water-propyl acetate (Nos. 12, 13 in Table 3), $n$-propanol-propyl propionate-water, methyl acetate-methanol-water (Nos. 3, 4 in Table 4), and nine binary systems (Nos. 14-22 in Table 3) containing acetic and propionic acids, both of which are self-associating components in vapor phase. Thus, calculation for the vapor-liquid equilibria is carried out on the basis of Eqs. (11) to (13), derived with a view to applying them to ordinary and heterogeneous liquid systems ${ }^{25}$, as well as to systems with a selfassociating component in vapor phase.

$$
\begin{aligned}
& \eta_{i}=\gamma_{i}^{\mathrm{I}} P_{i}^{0} x_{i}^{\mathrm{I}} / P=\gamma_{i}^{\mathrm{II}} P_{i}^{0} x_{i}^{\mathrm{II}} / P \\
& \eta_{1}+\eta_{12}+\sum_{i=2}^{n} \eta_{i}=1, \eta_{12}=K_{2} P \eta_{1}^{2}
\end{aligned}
$$


Table 3 Deviations of predicted values from observed vapor-liquid equilibria for binary systems

\begin{tabular}{|c|c|c|c|c|c|c|c|}
\hline \multirow[t]{2}{*}{ No. } & \multicolumn{2}{|c|}{ System } & \multirow{2}{*}{$\begin{array}{c}\text { Press. } \\
\text { [mmHg] }\end{array}$} & \multirow{2}{*}{$\begin{array}{l}\text { No. of } \\
\text { data } \\
\text { points }\end{array}$} & \multicolumn{2}{|c|}{$\begin{array}{c}\text { Absolute arithmetic } \\
\text { deviations in }\end{array}$} & \multirow[t]{2}{*}{ Ref. } \\
\hline & Component (1) & Component (2) & & & $y_{1} \times 1000$ & $t\left[{ }^{\circ} \mathrm{C}\right]$ & \\
\hline & \multicolumn{7}{|c|}{ Group $\mathrm{CH}_{2}+\mathrm{COO}$} \\
\hline 1 & Methyl formate & n-Hexane & 760 & 14 & 10 & 1.57 & 23 \\
\hline \multirow[t]{2}{*}{2} & Ethyl acetate & Butyl acetate & $"$ & 13 & 8 & 0.49 & 32 \\
\hline & \multicolumn{7}{|c|}{ Group $\mathrm{CH}_{2}+\mathrm{OH}+\mathrm{COO}$} \\
\hline 3 & Methanol & Methyl acetate & 760 & 7 & 14 & 1.31 & 6 \\
\hline 4 & Methanol & Ethyl acetate & $"$ & 19 & 11 & 0.99 & 1 \\
\hline 5 & Ethyl acetate & Ethanol & $"$ & 12 & 6 & 0.47 & 15 \\
\hline 6 & Ethyl acetate & $n$-Propanol & $"$ & 14 & 18 & 1.00 & 20 \\
\hline 7 & Ethyl acetate & $n$-Butanol & $"$ & 16 & 16 & 1.47 & 32 \\
\hline 8 & Propyl acetate & $n$-Propanol & $"$ & 11 & 7 & 0.45 & 26 \\
\hline 9 & $n$-Butanol & Butyl acetate & ", & 24 & 8 & 0.52 & 3 \\
\hline 10 & Propyl formate & $n$-Propanol & $"$ & 6 & 36 & - & 18 \\
\hline 11 & $n$-Propanol & Propyl propionate & $"$ & 7 & 26 & 1.79 & , \\
\hline $12 *$ & Ethyl acetate & Water & , & 22 & 49 & 1.80 & 15 \\
\hline \multirow[t]{2}{*}{$13^{*}$} & Water & Propyl acetate & ", & 7 & 49 & 2.37 & 33 \\
\hline & \multicolumn{7}{|c|}{ Group $\mathrm{CH}_{2}+\mathrm{OH}+\mathrm{COOH}$} \\
\hline 14 & Acetic acid & Water & 760 & 16 & 10 & 1.18 & 14 \\
\hline 15 & Propionic acid & Water & 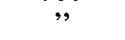 & 9 & 21 & 0.96 & 2 \\
\hline 16 & Acetic acid & Methanol & 706 & 20 & 21 & 1.23 & 29 \\
\hline 17 & Acetic acid & Ethanol & ", & 16 & 27 & 1.91 & $"$ \\
\hline 18 & Acetic acid & $n$-Propanol & ," & 14 & 27 & 2.60 & $"$ \\
\hline \multirow[t]{2}{*}{19} & Acetic acid & n-Butanol & $"$ & 18 & 30 & 2.28 & $"$ \\
\hline & \multicolumn{7}{|c|}{ Group $\mathrm{CH}_{2}+\mathrm{COO}+\mathrm{COOH}$} \\
\hline 20 & Acetic acid & Ethyl acetate & 760 & 6 & 9 & 0.69 & 9 \\
\hline 21 & Acetic acid & Propyl acetate & $"$ & 10 & 23 & - & 24 \\
\hline 22 & Acetic acid & Butyl acetate & $"$ & 10 & 15 & - & , \\
\hline
\end{tabular}

* heterogeneous liquid system

Table 4 Deviations of predicted values from observed vapor-liquid equilibria for ternary systems $(760 \mathrm{~mm} \mathrm{of} \mathrm{Hg}$ )

\begin{tabular}{|c|c|c|c|c|c|c|c|c|}
\hline No. & Component (1) & $\begin{array}{c}\text { System } \\
\text { Component (2) }\end{array}$ & Component (3) & $\begin{array}{l}\text { No. of } \\
\text { data } \\
\text { points }\end{array}$ & \multicolumn{3}{|c|}{ Absolute arithmetic deviations in } & Ref. \\
\hline & $\overline{\text { Group }} \overline{\mathrm{CH}_{2}+\mathrm{OH}}$ & $+\mathrm{COO}$ & & & & & & \\
\hline 1 & Ethyl acetate & Ethanol & Buthyl acetate & 77 & 23 & 12 & 0.38 & 32 \\
\hline 2 & Ethyl acetate & Ethanol & n-Butanol & 88 & 34 & 11 & 1.05 & $"$ \\
\hline $3^{*}$ & $n$-Propanol & Propyl propionate & Water & 19 & 65 & 30 & 1.02 & 19 \\
\hline $4^{*}$ & Methyl acetate & Methanol & Water & 32 & 43 & 23 & 2.27 & 4 \\
\hline
\end{tabular}

* heterogeneous liquid system

$$
\left.\begin{array}{l}
y_{1}=\left(\eta_{1}+2 \eta_{12}\right) /\left(\eta_{1}+2 \eta_{12}+\sum_{i=2}^{n} \eta_{i}\right) \\
y_{j}=\eta_{j} /\left(\eta_{1}+2 \eta_{12}+\sum_{i=2}^{n} \eta_{i}\right)
\end{array}\right\}
$$

In the above equations it has been assumed that the formation of higher aggregates than dimer for an associating component is negligible in vapor phase. Also, $x_{i}^{\mathrm{Y}}$ and $x_{i}^{\mathrm{II}}$ are, respectively, the mole fraction of component $i$ in the two liquid phases I and II in equilibrium and are evaluated ${ }^{22,37)}$ from the conditions of liquid-liquid equilibria by a modified NewtonRaphson method. It naturally follows that in the region where a system becomes one constituted by a single liquid phase $x_{i}^{\mathrm{I}}=x_{i}^{\mathrm{II}}=x_{i}, \gamma_{i}^{\mathrm{I}}=\gamma_{i}^{\mathrm{II}}=\gamma_{i}$. In the equations $\eta_{i}$ represents true mole fraction in the vapor phase and subscripts 1 and 12 denote, respectively, an associating component monomer and a dimer. When applied to a system not containing associating components like acetic acid or propionic acid, $\eta_{12}=0, \eta_{1}=y_{1}$ and $\eta_{j}=y_{j}$. Activity coefficients are predicted by applying Eqs. (7) to (10) on the basis of the ASOG model.

Prediction of vapor-liquid equilibria has been made on the basis of an ASOG model for 22 isobaric binary systems. Table 3 shows the deviations between predicted and observed vapor compositions and bubble points. As indicated in Table 3, the results agree fairly well with observed values. Figures 2 to 5 compare predicted and observed vapor compositions for the ethyl acetate-ethanol, acetic acid-water, acetic acid-methanol and ethyl acetate-water systems.

Prediction of vapor-liquid equilibria was made for four isobaric ternary systems. A comparison of predicted and observed vapor compositions and bubble points appears in Table 4.

\section{Prediction of Quaternary Vapor-Liquid Equilibria with Esterification}




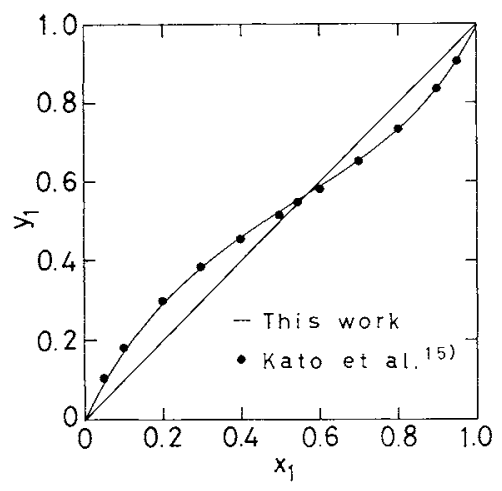

Fig. 2 Vapor-liquid equilibria for ethyl acetate (1)ethanol (2) system at $760 \mathrm{~mm}$ of $\mathrm{Hg}$

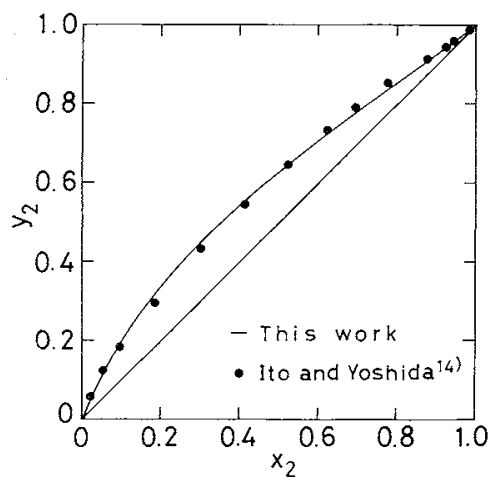

Fig. 3 Vapor-liquid equilibria for acetic acid (1)water (2) system at $760 \mathrm{~mm}$ of $\mathrm{Hg}$

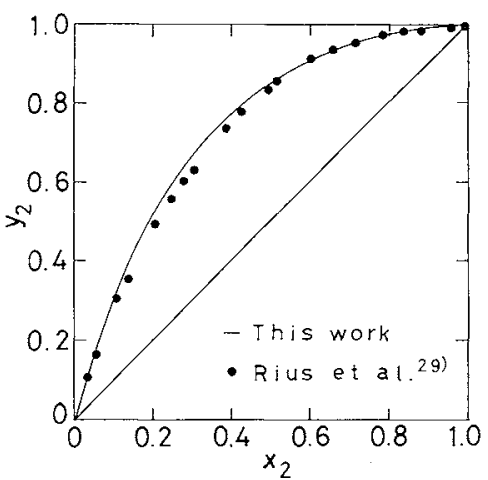

Fig. 4 Vapor-liquid equilibria for acetic acid (1)methanol (2) system at $706 \mathrm{~mm}$ of $\mathrm{Hg}$

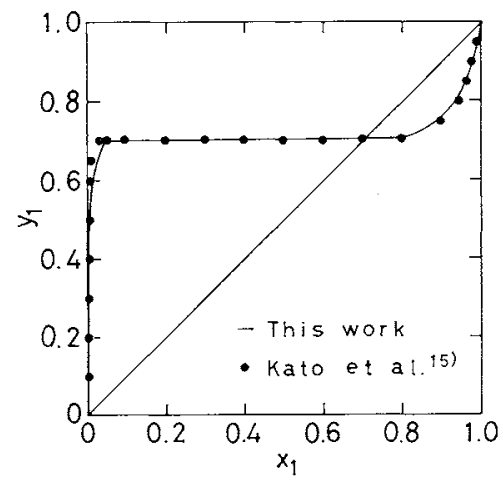

Fig. 5 Vapor-liquid equilibria for ethyl acetate (1)water (2) system at $760 \mathrm{~mm}$ of $\mathrm{Hg}$

Table 5 Deviations of predicted values from observed vapor-liquid equilibria for quaternary systems with esterification $(760 \mathrm{~mm}$ of $\mathrm{Hg}$ )

\begin{tabular}{|c|c|c|c|c|c|c|c|c|c|c|c|}
\hline \multirow[t]{2}{*}{ No. } & \multirow{2}{*}{$\begin{array}{l}\text { Component } \\
\text { (1) }\end{array}$} & \multirow{2}{*}{$\begin{array}{l}\text { Component } \\
\text { (2) }\end{array}$} & \multirow{2}{*}{$\begin{array}{l}\text { System } \\
\text { Component } \\
\text { (3) }\end{array}$} & \multirow{2}{*}{$\begin{array}{l}\text { Component } \\
\text { (4) }\end{array}$} & \multirow{2}{*}{$\begin{array}{l}\text { No. of } \\
\text { data } \\
\text { points }\end{array}$} & \multicolumn{5}{|c|}{ Absolute arithmetic deviations in } & \multirow[t]{2}{*}{ Ref. } \\
\hline & & & & & & $y_{1}$ & $y_{2}$ & $y_{3}$ & $y_{4}$ & & \\
\hline 1 & Acetic acid & Ethanol & Water & Ethyl acetate & 270 & 12 & 11 & 21 & 21 & 1.47 & 12 \\
\hline 2 & Acetic acid & $i$-Propanol & Water & $i$-Propyl acetate & 243 & 12 & 26 & 28 & 33 & 1.52 & 21 \\
\hline 3 & Acetic acid & $n$-Butanol & Water & Butyl acetate & 143 & 22 & 14 & 34 & 19 & 2.16 & 11 \\
\hline
\end{tabular}

Prediction of vapor-liquid equilibria with esterification was made on the basis of an ASOG model for three isobaric quaternary systems, acetic acidethanol-water-ethyl acetate, acetic acid-i-propanolwater- $i$-propyl acetate, and acetic acid- $n$-butanolwater-butyl acetate. It has been pointed out ${ }^{11,12,21)}$ that these esterification systems have two liquid phase regions within a range of approximately $70^{\circ}$ $100^{\circ} \mathrm{C}$. Further, they contain acetic acid, an associating component in vapor phase. Therefore, calculation for vapor-liquid equilibria is carried out on the basis of Eqs. (11) to (13), which appeared earlier and which are applicable to systems having two liquid phases and a vapor associating component. Activity coefficients are calculated on the basis of ASOG from Eqs. (7) to (10) using the constants shown in Table 2.

Table 5 shows the deviations between predicted and observed vapor compositions and bubble points for three esterification systems. The observed values employed for comparison with the predicted ones are those obtained by Komatsu, Hirata et al. ${ }^{11,12)}$ for the acetic acid-ethanol-water-ethyl acetate and acetic acid-n-butanol-water-butyl acetate systems and by $\mathrm{Nishi}^{21)}$ (values evaluated by correlation ${ }^{12)}$ ) for the acetic acid-i-propanol-water- $i$-propyl acetate system.

\section{Conclusion}

To discuss prediction of vapor-liquid equilibria with esterification on the basis of the ASOG model, the group Wilson parameters for any system made up of $\mathrm{CH}_{2}, \mathrm{OH}, \mathrm{COO}, \mathrm{COOH}$ groups were determined in the $40^{\circ}-100^{\circ} \mathrm{C}$ range by an ebulliometric method. By using the parameters so determined, vapor-liquid equilibria predicted for three quaternary esterification systems and 26 binary and ternary systems involving alcohols, water, paraffins, esters and carboxylic acids 
agreed well with observed values.

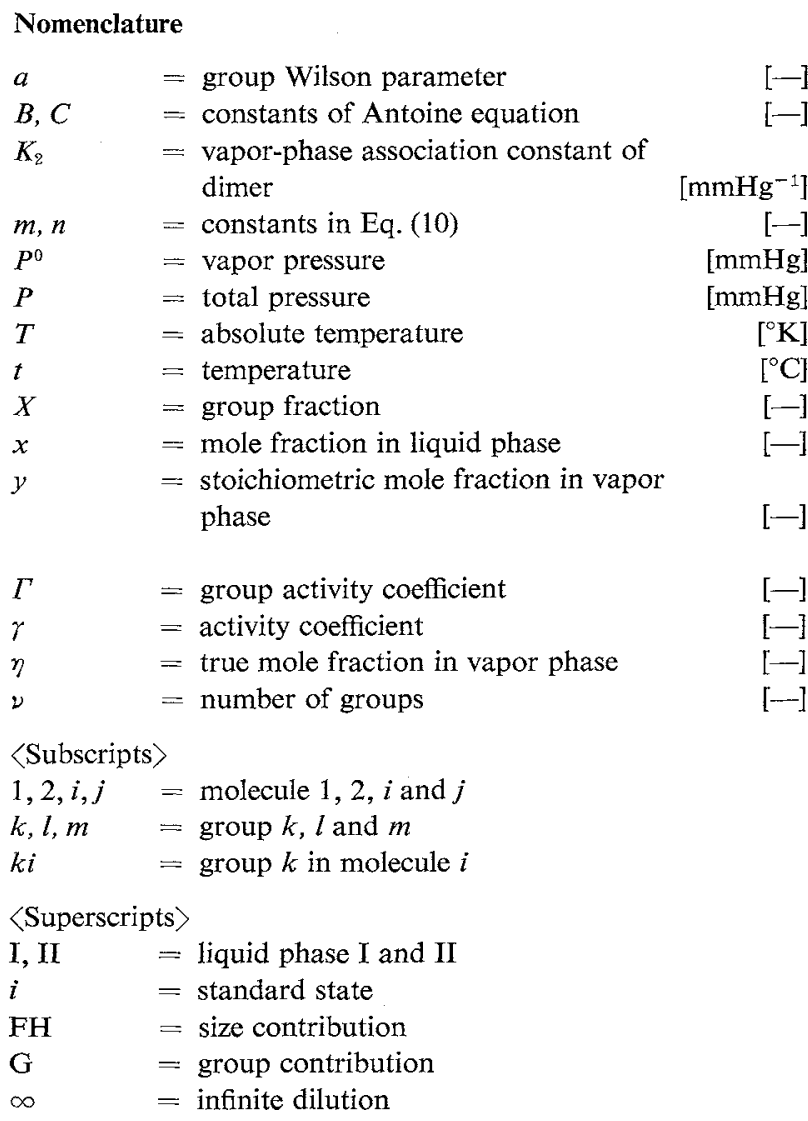

\section{Literature Cited}

1) Akita, K. and F. Yoshida: J. Chem. Eng. Data, 8, 484 (1963).

2) Aristovich, V. Yu., A. I. Levin and A. G. Morachevskii: Tr. Vses. Nauchin-Issled. Inst. Neftekhim. Protsessov, 5, 84 (1962).

3) Brunjes, A. S. and C. Furnas: Ind. Eng. Chem., 27, 396 (1935).

4) Crawford, A. G., G. Edwards and D. S. Lindsay: $J$. Chem. Soc., 1054 (1949).

5) Derr, E. L. and C. H. Deal: Int. Chem. Eng., Symp. Ser., 32, part 3, 40 (1969).

6) Doviroserdov, L. L. and I. V. Bagrov: Zh. Prikl. Khim., 40, 875 (1967).

7) Ellis, S. R. M. and D. A. Jonah: Chem. Eng. Sci., 17, 971 (1962).

8) Fredenslund, A., R. L. Jones and J. M. Prausnitz: AIChE J., 21, 1086 (1975).

9) Garner, F. H., S. R. M. Ellis and C. J. Pearce: Chem. Eng. Sci., 3, 48 (1954).
10) Gautreaux, M. F. and J. Coates: AIChE J., 1, 476 (1955).

11) Hirata, M. and H. Komatsu: Kagaku Kogaku,30, 129 (1966).

12) Hirata, M. and H. Komatsu: ibid., 30, 989 (1966).

13) Hirata, M., H. Komatsu and Y. Misaki: ibid., 31, 1184 (1967).

14) Ito, T. and F. Yoshida: J. Chem. Eng. Data, 8, 315 (1963).

15) Kato, M. H. Konishi and M. Hirata: ibid., 15, 435 (1970).

16) Kojima, K. and M. Kato: Kagaku Kögaku, 33, 769 (1969).

17) Marek, J. and G. Standard: Collect. Czech. Chem. Commun., 19, 1074 (1954).

18) Mozzhukhin, A. S., V. A. Mitropolskaya, L. A. Serafinov, A. I. Torubarov and T. C. Rudakovskaya: Zh. Fiz. Khim., 41, 227 (1967).

19) Mozzhukhin, A. S., L. A. Serafinov, V. A. Mitropolskaya and L. M. Sankina: ibid., 41, 1687 (1967).

20) Murti, P. S. and M. Van Winkle: J. Chem. Eng. Data, 3, 72 (1958).

21) Nishi, Y.: Kagaku Kōgaku, 35, 1257 (1971).

22) Null, H. R.: "Phase Equilibrium in Process Design", p. 211, Wiley-Interscience (1970).

23) Ogorodnikov, S. K., V. B. Kogan and M. S. Nemtsov: $Z h$. Prikl. Khim., 34, 581 (1961).

24) Othmer, D. F.: Ind. Eng. Chem., 35, 614 (1943).

25) Perry, R. H. and C. H. Chilton: "Chemical Engineers Handbook", 5th ed., section 13, p. 10 (1973).

26) Pick, J., E. Hala and V. Fried: Collect. Czech. Chem. Commun., 24, 1589 (1959).

27) Ratcliff, G. A. and K. C. Chao: Can. J. Chem. Eng., 47, 148 (1969).

28) Ritter, H. L. and J. H. Simons: J. Am. Chem. Soc., 58, 2585 (1936).

29) Rius, A., J. L. Otero and A. Macarron: Chem. Eng. Sci., 10, 105 (1959).

30) Ronc, M. and G. A. Ratcliff: Can. J. Chem. Eng., 49, 825 (1971).

31) Scheller, W. A., J. L. Petricek and G. C. Young: Ind. Eng. Chem., Fundam., 11, 53 (1972).

32) Shono, H., N. Kanazawa, M. Hashitani, H. Komatsu and M. Hirata: Kogyo Kagaku Zasshi, 72, 815 (1969).

33) Smirnova, N. A. and A. G. Morachevskii: Zh. Fiz. Khim., 34, 2546 (1960).

34) Sugi, H, and T. Katayama: Preprints of the 41th Annual Meeting, The Soc. of Chem. Engrs., Japan, Sendai, April (1976).

35) Suzuki, I., H. Komatsu and M. Hirata: J. Chem. Eng. Japan, 3, 152 (1970).

36) Tochigi, K. and K. Kojima: ibid., 9, 267 (1976).

37) Tochigi, K. and K. Kojima: ibid., 10, 61 (1977).

38) Tochigi, K. and K. Kojima: ibid., 10, 343 (1977).

39) Wilson, G. M. and C. H. Deal: Ind. Eng. Chem., Fundam., 1, 20 (1962). 